Wool

An Introduction to its Properties, Varieties, Uses and Production. By W. J. Onions. Pp. xvi+278. (London: Ernest Benn, Limited, 1962.) 55s.

$\mathrm{W}$ OOL and its industries are so varied that many years may pass before an entrant to this field of activity becomes aware of all its ramifications. Mr. Onions has written a book that will greatly shorten this apprenticeship. The structure, chemistry and physical properties of wool and hair are sketched in two chapters. Their growth from follicles is considered in a chapter that includes a survey of Mendelian principles as applied in progeny testing and breeding policies. Wool 'quality', which might be defined as 'fitness for purpose', is discussed in considerable detail, including recent attempts to add precision to the craftsman's tactual and visual judgment.

The book then turns to the marketing of wool, including briefly such financial aspects as the wool futures market. Wool production and types is the longest chapter in the book. It emphasizes the great variety of wools available to manufacturers, and the importance of wool in the economies of many countries, including the U.S.S.R., which is now the second largest wool producer. Skin wools, remanufactured wools and speciality hairs provide three short chapters. The book is rounded off with short descriptions of wool-processing systems and the man-made fibres used by the industry.

Wool has an enviable history among world commodities and much specialist literature is available on different facets of its production and use. Mr. Onions is the first author to attempt a comprehensive survey, and he has succeeded admirably in this difficult task. His book is a sketch of wool and its industries, and readers seeking more detailed information will find help in the references and lists of further reading provided at the end of each chapter. A list of books on the history of wool would have been a stimulating addition, for wool has a place in history that is both fascinating and unique.

The book is excellently produced and can be recommended without reserve to students and to anyone seeking knowledge of wool and its industries in the 1960's.

\section{Elementary Chemical Thermodynamics}

By Bruce H. Mahan. (General Chemistry Monograph Series.) Pp. $\mathrm{x}+$ 155. (Now York and Amsterdam: W. A. Benjamin, Inc., 1963.) 2.15 dollars paper-back; 4.35 dollars cloth-back.

HIS book is divided into four sections, namely, an introduction, the First Law of Thermodynamics, the Second Law of Thermodynamics and, finally, applications of principles. In the introduction there is a very good deseription of what thermodynamics is about; its usefulness is discussed and its limitations made clear. Tho laws of thermodynamics aro presented as stemming from observation; generalizations are stated clearly in words and in mathematical terms. Mathematical development is clear and interesting and most conclusions are reinforced with vorbal description. Diagrams to illustrate the text are timely and vory well presented.

So often, students find thormodynamies difficult, not simply because it contains a number of abstractions, but because thoy fail to see why the abstractions need to be created at all. The strength of this book lies in its attempt to justify the diffieult notions. Reasons aro given for proposing tho ideas of heat, work, internal energy, enthalpy, bond-energy, entropy and free energy. These ideas are also reinforced by giving tables of values for common substances in their Standard States. Lists like this aro interesting and thought-provoking. Clarity is further attempted by giving molecular interpretations of the ideas-an approach not without its dangers.

Ideas are illustrated by worked examples and a number of interesting problems are given at the end of oach section. It is a pity that answers are not provided.
The chapter dealing with appliołtions touches on phase equilibria, ideal solutions, and the ionization of weak acids.

This is a most attractive book, and will make a useful contribution to work in the third-year sixth form or in the first year at university.

D. C. Frrth

\section{The Shape of Carbon Compounds}

An Introduction to Organic Chomistry. (The General Chemistry Monograph Series.) By Werner Herz. Pp. xii + 152. (New York and Amsterdam: W. A. Benjamin, Inc., 1963.) 2.15 dollars paper-back; 4.35 dollars cloth-back. T is difficult to be enthusiastic about The Shape of I Carbon Compounds. Its title and the high standard set by this Benjamin Series promised an exciting account of one aspect of organic chemistry at university-level. The author, however, does not regard this as a text-book for a single course within an academic year, but has in mind students who would not later be given a formal course in organic chemistry.

The chapters of the book, which cover the shape of organic compounds, discuss atomic and molecular orbitals, single and multiple bonds, the de-localization of $\pi$-eloctrons in resonance systems and optical activity. The treatment is entirely theoretical and could be lifeless to a student who was not following a parallel practical course. These chapters could be read by a student in the first-year after the Advanced Level examination of the General Certificate of Education. However, almost half the book is on the making and breaking of bonds, and one wonders if these topics are within the scope of the title. The overall effect of the book is one of disjointedness and purposelessness. Subjects like the relation of the shape of large molecules (rubber, protein, nueleic acids, etc.) to their physical properties are absent, and would have given more meaning to this geometrical treatment. Organic chemists have a keon awareness of the geometry of molecules and the interaction of groups within them, and a discussion of this is surely the duty of this book.

There are, in addition, more misprints than one would expect.

D. M. RUSSELL

\section{Advances in Applied Microbiology}

Vol. 5. Edited by Wayne W. Umbreit. Pp. xi+385. (Now York: Academic Pross, Inc.; London: Academic Press, Inc. (London), Ltd., 1963.) $93 s$.

THE fifth volume in this series contains ten articles covering the usual broad range of topics. The article by $\mathrm{S}$. A. Waksman, who summarizes the published literature on actinomycetos and their antibiotics during the early 1960's, is little more than a useful catalogue, but the other contributions cover less crowded fields and make readable review articles. A. Albert discusses ways in which selective toxic agents act on bacteria, fungi, viruses and protozoa; G. F. Gause considers the possible uses of mutants of micro-organisms as model systems simulating the metabolic disturbances characteristic of malignancy in tumour cells; G. V. Levin provides persuasive argument for the increased use of isotopes for the rapid determination of microbial contamination in tho spheres of public health, medicine and bacteriological warfare; W. R. Lockhart and R. W. Squires diseuss the value of controlled aeration in fermentations; S. K. Long and R. Patrick describe microbial methods for the production of 2,3-butylene glycol; F. Reusser contributes an excellent discussion of the factors tending to cause degeneration of microbial cultures during repeated transfer; A. D. Webb and J. L. Ingraham describe the composition and biosynthesis of the fusel oil formed during yeast fermentation; R. T. Ross shows that the durability of paint films can be seriously impaired by microbial action, and J. B. Davis speculates about the possibilities, seemingly rather remote, of using microbial action to generate olectricity.

This is one of the better volumes of the series. It is worth noting that the editors invite suggestions for topics to be covered in future volumes. J. W. G. Porter 